JSIP: Jurnal Studi Ilmu Pemerintahan

Volume 2, No 1 Februari 2021

ISSN: 2722-7405

\title{
IMPLEMENTASI KEBIJAKAN PELAYANAN KARTU TANDA PENDUDUK ELEKTRONIK (E-KTP) DI KANTOR CAMAT RABA KOTA BIMA
}

\author{
Taufik Irfadat ${ }^{1}$ \\ Niken Ardiansyah ${ }^{2}$ \\ Haeril $^{3}$
}

1,23Sekolah Tinggi Ilmu Sosial dan Ilmu Politik (STISIP) Mbojo-Bima, Indonesia

\begin{tabular}{l}
\hline Article Info \\
\hline Keyword: \\
Policy \\
Service $^{2}$ \\
Electronic $_{\text {Signature Cards }}{ }^{3}$ \\
\\
Kata Kunci: \\
Kebijakan \\
Pelayanan \\
Kartu \\
Tanda \\
Penduduk Elektronik
\end{tabular}

\begin{abstract}
:
The purpose of this study was to determine the friendliness of employees in the implementation of identity card service (E-KTP) in the office of the Camat Raba Kota Bima, and the ability of employees to answer questions and information about the service of identity cards (E-KTP) in the office of the Camat Raba Kota Bima. The population of this study were all 1,100 respondents from 11 Kelurahan, Kecamatan Raba Kota Bima. Sampling using the Quota sampling technique by determining the number of respondents who were set as 100 (one hundred) people accidentally by giving a questionnaire to the respondent. With the type of quantitative research then data collection techniques are observation, questionnaires, and literature study. The collected data were then analyzed with data analysis techniques using SPSs 16.0 for windows and a Likert scale. Most of the service policies for the making of electronic identity cards (eKTP) stated that they were "good" (70\%), which stated "not good" as many (14.5\%) of respondents and as many (15.5\%) of respondents rated " not good". The weakness of this dimension lies in the willingness to provide assistance to the community without being asked
\end{abstract}

\section{Abstrak:}

Tujuan penelitian ini untuk mengetahui keramahan pegawai dalam pelaksanaan pelayanan kartu tanda penduduk (E-ktp) di kantor camat raba kota bima, dan kemampuan pegawai dalam menjawab pertanyaan dan informasi tentang pelayanan kartu tanda penduduk (E-ktp) di kantor camat raba kota bima. Populasi dari penelitian ini adalah seluruh masyarakat dari 11 Kelurahan Kecamatan Raba kota bima sejumlah 1.100 responden. penarikan sampel dengan menggunakan teknik Quota sampling dengan menetapkan jumlah responden yang ditetapkan sebanyak $\mathbf{1 0 0}$ (seratus) orang secara aksidental dengan memberikan kuisioner kepada responden. Dengan tipe penelitian kuantitatif kemudian teknik pengumpulan data yaitu observasi, quisioner, dan studi kepustakaan. Data yang terkumpul kemudian di analisa dengan teknik analisis data menggunakan spss 16.0 for windows serta skala likert. Kebijakan pelayanan program pembuatan Kartu Tanda Penduduk elektronik (e-KTP) dari sebagian besar menyatakan "baik" (70\%), yang menyatakan "kurang baik" sebanyak $(14,5 \%)$ responden serta sebanyak $(15,5 \%)$ responden menilai "tidak baik". Letak sisi lemah dimensi ini adalah kemauan untuk memberikan bantuan kepada masyarakat tanpa diminta.

\section{PENGANTAR}

Terkait dengan mutu pelayanan memiliki sisi lemah yang terletak pada kemauan untuk memberikan bantuan kepada masyarakat tanpa diminta mesti diperbaiki meskipun kelemahan sebagaimana dimaksud bukan semata - mata berangkat dari pegawai. didominasi oleh penilaian "baik", mesti dipertahankan dan terus ditingkatkan pada waktu-waktu 
selanjutnya. Mutu pelayanan dalam pembuatan Kartu Tanda Penduduk elektronik (e-KTP), hal yang mesti diwaspadai dan diantisipasi agar tidak terus memburuk dengan cara melaksanakan upaya-upaya pembinaan dan melengkapi sarana / prasarana pelayanan.

Kota Bima, kendati masih berumur sangat muda, kini telah menepati posisi yang sangat strategis sebagai pintu gerbang yang menghubungkan wilayah Indonesia Timur; sehingga menjadikannya sebagai sentra ekonomi, pendidikan dan lain-lain. Predikat yang disandangnya tersebut akan memberikan dampak terhadap masalah kependudukan, dimana populasi penduduk semakin besar sebagai akibat dari tingginya tingkat pertumbuhan penduduk dan urbanisasi yang pada akhirnya akan berdampak pada masalah kependudukan termasuk pelayanan Kartu Tanda Penduduk kepada masyarakat.

Pemerintah Kota Bima sebagai bagian integral dari Negara Kesatuan Republik Indonesia, tentunya juga melaksanakan pelayanan kepada masyarakat untuk ikut menyukseskan program Penerapan Kartu Tanda Penduduk Elektronik (e-KTP) sebagaimana dimaksud. Pada taraf implementasi pelayanan Kartu Tanda Penduduk Elektronik (e-KTP) dimaksud dilaksanakan oleh aparatur pada masing-masing kantor Kecamatan. Sebagai sebuah program yang masih sangat baru, dalam proses penyelenggaraan pelayanan Kartu Tanda Penduduk Elektronik (e-KTP) tentunya melahirkan berbagai penilaian atau persepsi dari masyarakat baik dalam hal kemampuan aparatur pelaksana maupun berbagai hal lain yang berhubungan langsung atau tidak berhubungan langsung dengan kualitas pelayanan kepada masyarakat.

Kecamatan Raba yang memiliki 11 kelurahan sebagai bagian dari wilayahnya sejak tahun 2012 lalu telah memberikan pelayanan pembuatan dan pendokumentasikan program Nasional Penerapan Kartu Tanda Penduduk Elektronik (e-KTP) diwilayah Kota Bima. Sebagai salah satu wilayah kecamatan yang memiliki luas wilayah yang besar, jumlah penduduk dan kelurahan yang paling banyak di Kota Bima, tentunya aparatur yang ada dirasa tidak mencukupi untuk melayani warga masyarakat yang banyak pula. Selama peneliti melakukan pra penelitian baik sebelum mengajukan judul skripsi maupun selama melakukan penelitian, peneliti mendapati kenyataan begitu tidak berimbangnya jumlah pegawai atau staf yang ada pada pada Kantor Camat Raba dengan jumlah warga masyarakat yang harus dilayani pada program Kartu Tanda Penduduk Elektronik (e-KTP) yang lalu

\section{Rumusan masalah}

1. Bagaimana bentuk keramahan pegawai dalam memberikan pelayanan Kartu Tanda Penduduk Elektronik (e-KTP) pada Kantor Camat Raba Kota Bima

2. Bagaimana penjelasan pegawai dalam menjawab pertanyaan terkait pelayanan Kartu Tanda Penduduk Elektronik (e-KTP) pada Kantor Camat Raba Kota Bima

3. Bagaimana kemampuan pegawai dalam mengoperasikan peralatan e-ktp dalam pelayanan Kartu Tanda Penduduk Elektronik (e-KTP) pada Kantor Camat Raba Kota Bima

\section{STUDI LITERATUR}

Pada konteks pelayanan Administrasi Kependudukan terkhusus lagi terkait dengan Kartu Tanda Penduduk, secara nasional berdasarkan pada ketentuan Undang-undang Nomor 23 Tahun 2006 tentang Administrasi Kependudukan, telah diprogramkan 3 (Tiga) program strategis nasional di bidang kependudukan dan pencatatan sipil (2010-2020) yang meliputi Pemutakhiran Data Kependudukan, Penerbitan Nomor Induk Kependudukan (NIK) dan Penerapan KTP Elektronik." (Direktur Jenderal Kependudukan dan Pencatatan Sipil, 4:2011). Sementara itu Pelayanan Publik Berdasarkan Undang-undang Nomor 25 Tahun 2009 Tentang Pelayanan Publik. "Pelayanan Publik meliputi pelayanan barang publik dan jasa publik serta 
pelayanan administratif yang diatur dalam peraturan perundang-undangan. Dalam ruang lingkup tersebut, termasuk pendidikan, pengajaran, pekerjaan dan usaha, tempat tinggal, komunikasi dan informasi, lingkungan hidup, kesehatan, jaminan sosial, energi, perbankan, perhubungan, sumber daya alam, pariwisata, dan sektor strategis lainnya. (Pasal 5 UU No 25 Tahun 2009).

Persepsi menurut Mar'at (1992:108) adanya dua komponen pokok yaitu seleksi dan interpretasi. Seleksi yang dimaksud adalah proses penyaringan terhadap stimulus pada alat indera. Stimulus yang ditangkap oleh indera terbatas jenis dan jumlahnya, karena adanya seleksi. Hanya sebagian kecil saja yang mencapai kesadaran pada individu. Individu cenderung mengamati dengan lebih teliti dan cepat terkena hal-hal yang meliputi orientasi mereka.Interpretasi sendiri merupakan suatu proses untuk mengorganisasikan informasi, sehingga mempunyai arti bagi individu. Dalam melakukan interpretasi itu terdapat pengalaman masa lalu serta sistem nilai yang dimilikinya. Wasistiono (2003) dalam Sagita (2010) "pelayanan adalah pemberian jasa baik oleh pemerintah, pihak swasta atas nama pemerintah ataupun pihak swasta kepada masyarakat, dengan atau tanpa pembayaran guna memenuhi kebutuhan dan kepentingan masyarakat". Menurut Instruksi Presiden Nomor 1 Tahun 1995 tentang Perbaikan dan Peningkatan Mutu Pelayanan, dinyatakan bahwa hakekat pelayanan umum adalah : kesatu, meningkatkan mutu produktivitas palaksanaan tugas dan fungsi instansi pemerintah di bidang pelayanan umum; kedua, Mendorong upaya mengefektifkan sistem dan tata laksana pelayanan, sehingga pelayanan umum dapat diselenggarakan secara berdaya guna dan berhasil guna; ketiga, Mendorong tumbuhnya kreativitas, prakarsa dan peran serta masyarakat dalam pembangunan serta dengan meningkatkan kesejahteraan masyarakat luas.

\section{Tinjauan tentang kebijakan}

Menurut ealua dan Kenneth prewitt yang dikutip oleh Charles o. jones kebijakan adalah sebuah ketetapan yang berlaku yang dicirikan oleh perilaku yang konsisten dan berulang bak oleh yang membuatnya maupun mereka yang mentaatinya. (a standing decision characterized by behavioral consistency and repetitiviness on the part of both those who make it and those who abide it). Budi winarno mengingatkan bahwa dalam memndefiniskan kebijakan haruslah melihat apa yang seharuSnya dilakukan daripada apa yang diusulkan mengenai persoalan. Alasannya adalah karena kebijakan merupaka suatu proses yangmencakup pula tahap implementasi dan evaluasi sehingga definisi kebijakan yang hanya menekankan pada apa yang diusulkan menjadi kurang memadai

\section{Kebijakan pelayanan E-ktp}

Berdasarkan undang-undang nomor 25 tahun 2009 pasal 4 tentang pelayanan publik, bahwa Seluruh penyelenggara pelayanan publik wajib mneyelenggarakan pelayanan dengan berazaskan kepentingan umum, kepastian hukum, kesamaan hak, keseimbangan hak dan kewajiban, keprofesionalan, partisipatif, persamaan perlakuan/tidak diskriminatif, keterbukaan, akuntabilitas, fasilitas dan perlakuan khusus bagi kelompok rentan, ketepatan waktu, kecepatan, kemudahan, dan keterjangkauan. Kemudian undang-undang nomor 25 tahun 2009 pasal 21 tentang pelayanan publik, komponen standar pelayanan yaitu dasar hukum, persyaratan, sistem, mekanisme, prosedur, jangka waktu penyelesaian, biaya/tarif, produk pelayanan, sarana, prasarana dan/atau fasilitas, kompetensi pelaksana. Pengawasan internal, penanganan pengaduan, saran, masukan, jumlah pelaksana, jaminan pelayanan yang memberikan kepastian pelayanan dilaksanakan sesuai standar pelayanan, jaminan keamanan dan keselamatan dalam bentuk komitmen untuk memberikan rasa aman, bebas dari bahaya, dan resiko keragu-raguan, evaluasi kinerja pelaksana. Sedangkan menurut Moenir sebagaimana 
dikutip oleh Tangkilisan (2005), "pelayanan adalah proses pemenuhan kebutuhan melalui aktivitas orang lain secara langsung".

\section{Definisi kebijakan}

Menurut thomas r. Dye kebijakan adalah apa yang dilakukan oleh pemerintah dan yang tidak dilakukan oleh pemerintah. Dye mengatakan bahwa apabila pemerintah ingin melakukan sesuatu maka harus ada tujuanya dan kebijakan publik itu harus meliputi semua tindakan pemerintah atau pejabat pemerintah saja (inu kencana, 2007). Kemudian chandler dan plano mendefinisikan kebijakan publik adalah pemanfaatan yang strategis terhadap sumber-sumber daya yang ada untuk memecahkan masalah publik atau pemerintah (harbani pasolong 2010). (http://repository.uin-suska.ac.id/3988/3/BAB\%20II.pdf)

\section{METODE PENELITIAN}

Penelitian ini dilaksanakan di Kantor camat Raba Kota Bima sebagai tempat dilakukannya pelayanan kepada masyarakat terkait dengan Kartu Tanda Penduduk elektronik (e-KTP) sejak 20 april sampai 19 juni 2020. Dengan tipe penelitian deskriptif kuantitatif. Teknik pengumpulan data observasi, quisioner, dan penelitian pustaka selanjutnya setelah data terkumpul maka akan dianalisis data dengan mengumpulkan dan mengelompokkan data berdasarkan responden dan variabel. Kemudian instrumentnya yaitu skala likert dengan dasar penelitian pada Kantor camat Raba Kota Bima.

\section{HASIL DAN DISKUSI}

Dalam pelayanan masyarakat saat ini, pada dasarnya merupakan tugas nasional yang menjadi tanggung jawab instansi pemerintah maupun swasta, baik pada tingkat pusat, daerah maupun Kecamatan sampai Kelurahan/desa. Dalam rangka menyelenggarakan fungsi pelayanan kepada masyarakat di tingkat Kecamatan, Kantor Kecamatan Raba Kota Bima sebagai salah satu instansi pemerintah, memiliki lingkup tugas dan wewenang yang cukup luas. Aparat pada Kantor Kecamatan Raba Kota Bima dalam melaksanakan tugas pelayanan tersebut dituntut meningkatkan kualitas atau mutu pelayanannya, karena wawasan, daya kritis dan dinamika masyarakat semakin berkembang seiring dengan kemajuan ilmu pengetahuan dan teknologi dalam era globalisasi dewasa ini.

Dalam pelayanan masyarakat saat ini, pada dasarnya merupakan tugas nasional yang menjadi tanggung jawab instansi pemerintah maupun swasta, baik pada tingkat pusat, daerah maupun Kecamatan sampai Kelurahan/desa. Dalam rangka menyelenggarakan fungsi pelayanan kepada masyarakat di tingkat Kecamatan, Kantor Kecamatan Raba Kota Bima sebagai salah satu instansi pemerintah, memiliki lingkup tugas dan wewenang yang cukup luas. Aparat pada Kantor Kecamatan Raba Kota Bima dalam melaksanakan tugas pelayanan tersebut dituntut meningkatkan kualitas atau mutu pelayanannya, karena wawasan, daya kritis dan dinamika masyarakat semakin berkembang seiring dengan kemajuan ilmu pengetahuan dan teknologi dalam era globalisasi dewasa ini.

1. Kemauan Pegawai dalam menanyakan kesulitan atau masalah yang dihadapi Masyarakat

\begin{tabular}{|c|l|c|c|}
\hline No & \multicolumn{1}{|c|}{ Jawaban Responden } & Frekwensi & Persentase \\
\hline 1 & Ya & $73 \%$ & $73 \%$ \\
\hline 2 & Jarang & $9 \%$ & $9 \%$ \\
\hline 3 & Tidak Pernah & $18 \%$ & $18 \%$ \\
\hline
\end{tabular}




\begin{tabular}{|c|c|c|}
\hline Jumlah & $100 \%$ & 100 \\
\hline
\end{tabular}

Sumber : Kuisioner Penelitian 2020

Jawaban di atas memberikan gambaran bahwa secara dominan (73\%) masyarakat yang mengurus Kartu Tanda Penduduk elektronik (e-KTP) di Kantor Kecamatan Raba Kota Bima menyatakan bahwa aparatur atau pegawai yang ada memiliki inisiatif untuk terlebih dahulu membuka ruang komunikasi dengan jalan bertanya ketika mendapatkan masyarakat yang memiliki masalah atau suatu kesulitan. Hal ini mencerminkan adanya kesadaran dari para pegawai bahwa masalah yang dihadapi masyarakat (pengurus e-KTP) sesungguhnya akan memberikan dampak dalam pelaksanaan tugas pelayanan mereka sendiri sehingga mesti dilakukan upaya - upaya preventif. Pada sisi lain, masih terdapat 18 orang (18\%) responden yang menyatakan bahwa pegawai tidak lebih dahulu menanyakan kesulitan atau masalah yang dihadapi masyarakat dan porsentasenya lebih besar jika dibandingkan dengan yang menyatakan jarang yakni sebesar 9 orang (9\%).

Kondisi seperti ini dapat dipahami karena biasanya ketika pegawai tengah melakukan suatu pekerjaan yang membutuhkan ketelitian dan ketekunan seperti pelayanan e-KTP, mereka mengerjakan secara serius dan berusaha untuk tidak mengalihkan perhatiannya pada hal - hal lain.

Table : Kesiapan pegawai dalam melayani masyarakat

\begin{tabular}{|c|l|c|c|}
\hline No & \multicolumn{1}{|c|}{ Akselerasi pelayanan } & Frekwensi & Persentase \\
\hline 1 & Cepat & $87 \%$ & $87 \%$ \\
\hline 2 & Sedang & $10 \%$ & $10 \%$ \\
\hline 3 & Lama & $2 \%$ & $2 \%$ \\
\hline 4 & Sangat lama & $1 \%$ & $1 \%$ \\
\hline \multicolumn{2}{|r|}{ Jumlah } & $100 \%$ & $100 \%$ \\
\hline
\end{tabular}

Sumber : Kantor camat Raba Kota Bima Tahun 2018

2. Keramahan Pegawai Dalam Menjawab Pertanyaan Serta Bersikap Sabar Dan Menjaga Kesantunan Dalam Pelayanan

\begin{tabular}{|c|l|c|c|}
\hline No & Jawaban Responden & Frekwensi & Persentase \\
\hline 1 & Ya & $90 \%$ & $90 \%$ \\
\hline 2 & Jarang & $8 \%$ & $8 \%$ \\
\hline 3 & Tidak Pernah & $2 \%$ & $2 \%$ \\
\hline \multicolumn{2}{r|}{ Jumlah } & $100 \%$ & $100 \%$ \\
\hline
\end{tabular}

Sumber : Kuisioner Penelitian 2020

Jawaban di atas memberikan gambaran bahwa secara dominan (90\%) masyarakat yang mengurus Kartu Tanda Penduduk elektronik (e-KTP) di Kantor Kecamatan RabaKota Bima menyatakan bahwa aparatur atau pegawai yang ada memiliki kemauan untuk memberikan jawaban atas pertanyaan - pertanyaan yang disampaikan oleh masyarakat serta 
melakukannya dengan penuh kesabaran dan menjaga kesantunan. Terkait masih adanya 8 orang $(8 \%)$ responden yang menyatakan bahwa pegawai jarang memberikan jawaban ketika ditanyakan sesuatu masalah serta menunjukkan sikap sabar dan santun; 2 orang (2\%) responden bahkan menyatakan pegawai "tidak“ memberikan jawaban ketika ditanyakan sesuatu masalah serta tidak adalah suatu masalah komunikasi yang tidak bisa dianggap remeh. Pada konteks pelayanan, kebuntuan komunikasi sekecil apapun akan membawa dampak yang kurang baik.

Tabel : Etika Pegawai Dalam Melayani Masyarakat

\begin{tabular}{|c|l|c|c|}
\hline No & Etika pegawai & Frekwensi & Persentase \\
\hline 1 & Sangat baik & $92 \%$ & $92 \%$ \\
\hline 2 & Baik & $6 \%$ & $6 \%$ \\
\hline 3 & Buruk & $2 \%$ & $2 \%$ \\
\hline 4. & Sangat Buruk & $0 \%$ & $0 \%$ \\
\hline \multicolumn{2}{r|}{ Jumlah } & $100 \%$ & $100 \%$ \\
\hline
\end{tabular}

Sumber : Kantor camat Raba Kota Bima Tahun 2018

3. Pegawai Memberikan Penjelasan Yang Mudah Dipahami

\begin{tabular}{|c|l|c|c|}
\hline No & Jawaban Responden & Frekwensi & Persentase \\
\hline 1 & Ya & $90 \%$ & $90 \%$ \\
\hline 2 & Jarang & $0 \%$ & $0 \%$ \\
\hline 3 & Tidak Pernah & $10 \%$ & $10 \%$ \\
\hline \multicolumn{2}{|c|}{ Jumlah } & $100 \%$ & $100 \%$ \\
\hline
\end{tabular}

Sumber : Kuisioner Penelitian 2020

Distribusi jawaban di atas memberikan gambaran bahwa secara dominan (90\%) masyarakat yang mengurus Kartu Tanda Penduduk elektronik (e-KTP) di Kantor Kecamatan Raba Kota Bima menyatakan bahwa aparatur atau pegawai yang ada memiliki kemauan untuk memberikan jawaban yang sederhana dan dapat dipahami dengan mudah oleh masyarakat, tidak satu orangpun (0\%) responden yang menyatakan (b) (Jarang) dan 10 orang $(10 \%)$ yang memilih alternatif jawaban (c) (Tidak). Memilih bahasa yang sederhana untuk memberi penjelasan atas suatu pertanyaan merupakan bentuk keharusan dalam berkomunikasi.

Tabel : kemudahan masyarakat dalam memperoleh informasi

\begin{tabular}{|c|l|c|c|}
\hline No & Akselerasi pelayanan & Frekwensi & Persentase \\
\hline 1 & Sangat Mudah & $89 \%$ & $89 \%$ \\
\hline 2 & Mudah & $7 \%$ & $7 \%$ \\
\hline 3 & Sulit & $2 \%$ & $2 \%$ \\
\hline
\end{tabular}




\begin{tabular}{|c|c|c|c|c|}
\hline 4. & Sangat Sulit & $2 \%$ & $2 \%$ & \\
\hline & Jumlah & $100 \%$ & $100 \%$ & $100 \%$ \\
\hline
\end{tabular}

Sumber : Kantor camat Raba Kota Bima Tahun 2018

4. Persepsi Masyarakat Terkait Kemampuan Pegawai Mengoperasikan Peralatan Pelayanan Dengan Mudah dan Cepat

\begin{tabular}{|c|l|c|c|}
\hline No & \multicolumn{1}{|c|}{ Jawaban Responden } & Frekwensi & Persentase \\
\hline 1 & Ya & $87 \%$ & $87 \%$ \\
\hline 2 & Jarang & $3 \%$ & $3 \%$ \\
\hline 3 & Tidak Pernah & $10 \%$ & $10 \%$ \\
\hline \multicolumn{2}{|c|}{ Jumlah } & $100 \%$ & $100 \%$ \\
\hline
\end{tabular}

Sumber : Kuisioner Penelitian 2020

Pada tabel tersebut di atas memperlihatkan bahwa keterampilan yang dimiliki pegawai pada Kantor Kecamatan Raba dalam mengoperasionalkan alat - alat pelayanan dapat dikategorikan terampil. Dari 100 orang responden yang telah memberikan jawaban atas kuisioner yang dibagikan, diperoleh data penelitian bahwa sebesar 87 orang $(87 \%)$ responden memilih jawaban (a) (Ya), 3 orang (3\%) responden yang menyatakan (b) (Jarang) dan 10 orang (10\%) yang memilih alternatif jawaban (c) (Tidak). Adanya pegawai yang kurang terampil (3\%) dan tidak terampil (10\%) pada dasarnya menurut hemat penulis disebabkan karena faktor dukungan pendidikan yang kurang memadai. Meski demikian, secara dominan dalam konteks pelayanan pembuatan e-KTP yang menggunakan peralatan berteknologi canggih secara global masyarakat menilai aparatur memiliki keterampilan yang baik.

Tabel : Akselerasi pemerintah kecamatan raba dalam merespon kebutuhan E-Ktp masyarakat

\begin{tabular}{|c|l|c|c|}
\hline No & \multicolumn{1}{|c|}{ Akselerasi pelayanan } & Frekwensi & Persentase \\
\hline 1 & Cepat & $80 \%$ & $80 \%$ \\
\hline 2 & Sedang & $14 \%$ & $14 \%$ \\
\hline 3 & Lama & $4 \%$ & $4 \%$ \\
\hline 4 & Sangat lama & $2 \%$ & $2 \%$ \\
\hline \multicolumn{2}{|c|}{ Jumlah } & $100 \%$ & $100 \%$ \\
\hline
\end{tabular}

Sumber : kantor camat raba kota bima tahun 2019

\section{Kesimpulan}

1. Kualitas pelayanan program pembuatan Kartu Tanda Penduduk elektronik (e-KTP) dari sebagian besar menyatakan "baik" (70\%), yang menyatakan "kurang baik" sebanyak $(14,5 \%)$ responden serta sebanyak $(15,5 \%)$ responden menilai "tidak baik".

2. Letak sisi lemah pada dimensi ini adalah kemauan untuk memberikan bantuan kepada masyarakat tanpa diminta, dimana dalam hal ini masih terdapat (40\%) 
responden yang menilai "kurang baik" dan sebesar (13\%) lainnya menilai "tidak baik". Jika kedua penilaian ini diakumulasi maka diperoleh angka sebesar (47\%) responden "tidak memberikan penilaian "baik".

3. Kualitas pelayanan program pembuatan Kartu Tanda Penduduk elektronik (e-KTP) didominasi penilaian "baik" oleh sebesar $(91,75 \%)$ responden, $(2,75 \%)$ responden meilai "kurang baik" serta (5,5\%) lainnya menilai "tidak baik".

\section{Saran}

1. Terkait dengan mutu pelayanan memiliki sisi lemah yang terletak pada kemauan untuk memberikan bantuan kepada masyarakat tanpa diminta mesti diperbaiki meskipun kelemahan sebagaimana dimaksud bukan semata-mata berangkat dari pegawai.

2. Didominasi oleh penilaian "baik", mesti dipertahankan dan terus ditingkatkan pada waktu-waktu selanjutnya. Mutu pelayanan dalam pembuatan Kartu Tanda Penduduk elektronik (e-KTP)

3. Hal yang mesti diwaspadai dan diantisipasi agar tidak terus memburuk dengan cara melaksanakan upaya-upaya pembinaan dan melengkapi sarana/prasarana pelayanan

\section{Daftar pustaka}

Taufik irfadat ${ }^{1}$, Haeril2 ${ }^{2}$, dan Nuranilawati $^{2}$, wawan mulyawan, Implementasi Kebijakan Pembangunan Berbasis Pemberdayaan Masyarakat Di Desa Rato Kecamatan Lambu Kabupaten Bima; Jurnal Komunikasi dan Kebudayaan ISSN.2443-3519 Volume 7 Nomor 1 Januari-Juni 2020

Taufik Irfadata, Nurlailab, Haerilc, Tauhidd, Dimensions of Public Services: A Portrait of Irony Facilities for Disabilities at the Sape Sub-District Office, Bima RegencyIndonesia International Journal of Social Sciences and Humanities Vol. 4 No. 3, December 2020, pages: 130-141 e-ISSN: 2550-7001, p-ISSN: 2550-701X

Arikunto, Suharsimin; 1998: Prosedur Penelitian Suatu Pendekatan Praktek, edisi revisi IV, Rineka Cipta Jakarta

Jalaluddin Rahmat, 2003.Psikologi Komunikasi. Remaja Rosdakarya: Bandung

Marat, 1982.Sikap Manusia, Perubahan serta Pengukurannya.Ghalia Indonesia:Bandung

Irfadat, taufik, tesis, 2018. Kualitas pelayanan publik pada kantor dinas kependudukan dan pencatatan sipil kota makassar.

Sinambela dkk, (2006). Reformasi Pelayanan Pbulik: Teori, Kebijakan, Dan Implementasi. Jakarta: Bumi Aksara.

Direktur Jenderal Kependudukan dan Pencatatan Sipil, 2011, Jurnal Kependudukan dan PencatatanSipil.

Undang-undang Nomor 25 Tahun 2009 Tentang Pelayanan Publik.

Undang-Undang Republik Indonesia Nomor 23 Tahun 2006 tentang Administrasi Kependudukan

Instruksi Presiden Nomor 1 Tahun 1995 tentang Perbaikan dan Peningkatan Mutu Pelayanan http://repository.uin-suska.ac.id/3988/3/BAB\%20II.pdf diakses tanggal 25 Mei 2020 